\title{
Study on Fouling and Cleaning of PVDF Membrane
}

\author{
Bofeng Zhang \& Shihu Ma (Corresponding author) \\ Key Laboratory of Hollow Fiber Membrane Material \& Membrane Process, Ministry of Education \\ Tianjin Polytechnic University, Tianjin 300160, China \\ Tel: 86-22-2458-5031_E-mail: zhangbofeng08@163.com
}

The research is funded by the National Key Scientific \& Technological Special Project for Water Pollution Control and Management. No. 2008ZX07314-001-11 (Sponsoring information).

\begin{abstract}
The effects of different water sources on the fouling of PVDF membrane are different. On the basis of the scientific appraisal, the correct cleaning process and cleaning reagent are selected to recover the flux and other performances of PVDF membrane. The results indicate that the TMP (transmembrane pressure) of PVDF membrane can be effectively recovered by CIP (clean-in-place) process, and almost reaches the initial level even under the circumstance that PVDF membrane has been used for a certain time and its TMP can not be recovered by either physical cleaning process or CEB (chemically enhanced backwashes).
\end{abstract}

Keywords: PVDF membrane, Membrane fouling, Membrane cleaning, Cleaning agent

\section{Preface}

PVDF membrane is easy to clean, and has advantages of high flux, fouling resistance, anti-corrosion, long service life and etc. It is widely applied in the municipal facilities, chemical industry, petrochemical industry, electric power industry, seawater desalination, gray water reuse, pharmaceutical industry, food industry and etc. The key issue of PVDF membrane in practical applications is the membrane fouling. The membrane fouling causes the declines of the membrane flux, filterability and etc., in turn restricts and challenges the vigorous development of PVDF membrane separation technology. An effective way of solving the issue of membrane fouling is to clean the membrane, and recover its flux, filterability and etc., in turn prolong its service life. Therefore, a rational and effective way of cleaning the fouled membrane is of the great significance.

\section{PVDF membrane fouling}

PVDF membrane fouling is defined as the process in which microparticles, colloidal particles, solute molecules or bacteria deposit onto the PVDF membrane surface or into the membrane pores such that the membrane pores are blocked or become smaller, and membrane resistance increases, in turn its performances (membrane flux and etc.) are deteriorated. The generalized membrane fouling can be divided into reversible fouling and irreversible fouling based on the attachment strength of particles to the membrane surface. Reversible fouling, caused by a gel layer resulted from reversible concentration polarization, can be removed by means of strong shear force of backwashing. The foulants causing reversible fouling include inorganic compounds (silicon, alumina, iron, calcium, manganese and etc.), organic compounds, as well as microorganisms, bacteria and their metabolites (Lin et al, 2009, p. 94-96, 99). Irreversible fouling, caused by irreversible absorption and blockage, is impossible to be removed by physical cleaning method. Ridgway et al (1988, p. 429-481) reported that the membrane fouling had three features in common: (1) Gradual decline of membrane flux; (2) Gradual decline of intercepting rate of minerals; (3) Gradual increase of TMP and pressure difference across the membrane.

\section{Foulants on PVDF membrane}

Water supply is divided into groundwater and surface water on the basis of the types of water source (Yan et al, 1999, p. 233-236). The foulants from groundwater mainly contain colloids and scaling ions. Colloids are mainly clays. Scaling ions consist of positive ions and negative ions, wherein positive ions mainly include $\mathrm{Ca}^{2+}, \mathrm{Mg}^{2+}, \mathrm{Na}^{+}$, as well as a small amount of $\mathrm{K}^{+}, \mathrm{Fe}^{2+}, \mathrm{Mn}^{2+}, \mathrm{Cu}^{2+}$ and etc.; and negative ions mainly include $\mathrm{HCO}_{3}^{-}, \mathrm{SO}_{4}^{2-}, \mathrm{Cl}^{-}$, as well as a small amount of $\mathrm{HSiO}_{3}^{-}, \mathrm{CO}_{3}^{2-}, \mathrm{NO}_{3}^{-}$and etc. The foulants from surface water mainly contain algae; suspensions and colloids such as bacteria, virus, humus, protein, microorganisms; water-soluble substances such as metal salt of $\mathrm{Fe}, \mathrm{Mn}, \mathrm{Si}, \mathrm{Ba}$ and etc. 
Wastewater is divided into domestic wastewater and industrial wastewater (Zhang et al, 2000, p. 1). Domestic wastewater, with a high value of $\mathrm{COD}_{\mathrm{Cr}}$, contains large amount of carbohydrate and nutrient elements in terms of $\mathrm{N}$, $\mathrm{P}$, $\mathrm{S}$ and etc, as well as detergent, various bacteria and microorganisms. Industrial wastewater, with a high acidity or alkalinity, contains large amount of suspensions and harmful substances such as pesticide, phenol, dye, polycyclic aromatic hydrocarbon, oil (Liu et al, 2005, p.156-208).

A wide range of processed water with various water qualities results in different foulants on PVDF membrane. Table 1 shows the foulants on PVDF membrane from different water sources.

There are very big differences among various industrial wastewaters. Table 2 shows the foulants on PVDF membrane from various industrial wastewaters (Yan et al, 1999, p. 233-236).

\section{PVDF membrane cleaning}

Although the gradual decline of membrane flux is an inevitable phenomenon during membrane filtration, PVDF membrane can be recovered by proper cleaning. Correct cleaning process and cleaning reagent should be selected on the basis of the investigation and analysis on the foulants. Table 3 shows the identification methods of various foulants.

Membrane can be cleaned either physically, biologically or chemically. Physical cleaning is effective on removing the cake layer on the PVDF membrane; chemical cleaning is effective on removing the minerals, inorganic substances, organic substances and microorganisms; whereas biological cleaning is effective on removing the foulants on and inside the membrane with biocides such as microorganisms and enzymes (Zhang et al, 2003, p. 187).

\subsection{Physical cleaning}

Physical cleaning uses water jet or water-air jet to wash the membrane surface. This process will not introduce new foulants and is easy to operate (Zhang et al, 2003, p. 187). It includes various processes in terms of low pressure-high flow rate cleaning, isostatic pressure cleaning, backflushing (Wang et al, 2005, p. 61-63), negative pressure cleaning (Wu et al, 1999, p. 52-55), mechanical scrub (Liu et al, 2003, p. 65-68), ultra-sonic cleaning (Kobayashi T et al, 2000 , p. 2980-2981), electrophoretic cleaning, hot water cleaning, circulation spray cleaning and etc.

A detailed introduction of physical cleaning is as follows:

(1) Forward flushing: the flushing water flows in the direction of influent water. Use the flushing water to wash through the particle deposits from raw water side to product water side. Either recycling mode or continuous mode can be used. The cleaning interval depends on the situation, but generally is 10 30 min.

(2) Backward flushing: the flushing water flows in the reverse direction of influent water. Use the flushing water to wash through the particle deposits from product water side to raw water side. Recycling mode can not be applied lest the product water is polluted by the flushing water. The cleaning interval depends on the situation, but generally is 10 20 $\mathrm{min}$.

(3) Air-water flushing: a measured volume of compressed air is introduced to the in-flow side during backward flushing. The upwardly rising air bubbles provide intensive frictions to remove the foulants which are flushed out through outlet.

\subsection{Chemical cleaning}

In practical operation, physical cleaning doesn't work when PVDF membrane is severely fouled. It is necessary to use chemical reagents. There are two types of processes for chemical cleaning: on-line cleaning and off-line cleaning.

(1) On-line cleaning: the in-service PVDF membrane is directly cleaned with chemical reagents.

(2) Off-line cleaning: PVDF membrane must be removed from service for a period of time, so that the membrane can be opened for chemical cleaning. This process can rapidly recover the flux of PVDF membrane.

Whichever process is used, it is important to correctly select the chemical reagent, reagent concentration, operating sequence and cleaning interval in view of the chemicals resistance of membrane, type of foulant and fouling degree. The commonly used chemical reagents include acid detergent (hydrochloric acid, for example), alkaline detergent (sodium hydroxide, for example), oxidant (sodium hypochlorite, for example), enzyme detergent, surfactant, chelating agent, disinfectant, complex agent and etc. Various foulants are removed with different detergents. Alkali, oxidant and alkaline detergent are used to remove organic foulants, whereas inorganic acid, organic acid and acid detergent are used to remove inorganic foulants (Lin et al, 2009, p. 94-96, 99). Table 4 shows the types of foulants and corresponding cleaning reagents.

\section{Cleaning experiment of PVDF membrane}

\subsection{Studied water sample}

The study is completed at Tianjin TEDA New Water Sources Technology Development Co., Ltd. The water sample is from the municipal wastewater which flows from SBR, through regulation pond, and into primary water container; then is processed with PVDF membrane of 8 inches. The technological process is expressed with the following flowsheet. 
Raw water $\rightarrow$ grid $\rightarrow$ SBR $\rightarrow$ horizontal settling pond $\rightarrow$ regulation pond $\rightarrow$ security filter $\rightarrow$ primary water tank $\rightarrow$ PVDF membrane assembly of 8 inches $\rightarrow$ fresh water tank $\rightarrow$ water output

Table 5 and table 6 respectively reveal the qualities of outlet water from SBR and regulation pond.

\subsection{Used equipment}

The equipment is a PVDF membrane assembly of 8 inches from Tianjin MOTIMO Membrane Technology Co., Ltd. This membrane assembly has advantages of large loading capacity, high water output per membrane and etc. The material used to make the equipment is PVDF fiber developed by Tianjin MOTIMO Membrane Technology Co., Ltd. This PVDF fiber has a molecular weight cutoff of $0.03 \mu \mathrm{m}$ and pore size of $0.2 \mu \mathrm{m}$. The technological process of the above-mentioned membrane assembly is expressed with the following flowsheet.

(1) Process of water production: forward flushing $\rightarrow$ water output $\rightarrow$ air-water flushing $\rightarrow$ backward flushing $\rightarrow$ forward flushing

(2) CEB process: chemically enhanced air-water flushing $\rightarrow$ chemically enhanced backward flushing $\rightarrow$ introduction of acid / reagent / acid + reagent $\rightarrow$ immersing $\rightarrow$ chemically enhanced air-water flushing $\rightarrow$ chemically enhanced backward flushing $\rightarrow$ forward flushing $\rightarrow$ water output

(3) CIP process: CIP air-water flushing $\rightarrow$ CIP backward flushing $\rightarrow$ introduction of cleaning chemicals (one chemicals or combination of several chemicals) $\rightarrow$ circulating $\rightarrow$ immersing $\rightarrow$ CIP air-water flushing $\rightarrow$ CIP backward flushing $\rightarrow$ forward flushing until $\mathrm{pH}$ is $7 \rightarrow$ water output

\subsection{Result and analysis}

The changes of TMP of the membrane assembly before and after CEB process had been continuously investigated for four months. Figure 1 exhibits the observed results.

From figure 1, we can see that the water output had increased from $3 \mathrm{t} / \mathrm{h}$ to $3.7 \mathrm{t} / \mathrm{h}$ from early April until mid-July, and TMP of the membrane assembly had changed little $(40 \sim 60 \mathrm{kPa})$ in this period. The TMP was over $100 \mathrm{kPa}$ before CEB and declined to the normal level after CEB on 29 March, 17 April and 24 April. It indicated that the membrane fiber was not severely fouled and the TMP was effectively recovered by CEB. However, after 17 July, the TMP before CEB had rapidly increased up to $120 \mathrm{kPa}$, so had the TMP after CEB. It indicated that the membrane fiber was severely fouled and the TMP can not be effectively recovered only by CEB. Therefore, it is necessary to apply CIP process to improve the cleaning effects of the membrane assembly.

The turbidity, $\mathrm{COD}_{\mathrm{Cr}}$ and total bacterial count of the feed water and the permeate water are respectively shown in Figure 2 4.

Figure 2 exhibits that the feed water has a high turbidity of $1 \sim 3$ NTU, however, the permeate water has a very low turbidity and is stable. Figure 3 exhibits that $\mathrm{COD}_{\mathrm{Cr}}$ of the permeate water is much lower than that of the feed water. Figure 4 exhibits that the total bacterial count of the feed water is high and remarkably different for different dates, whereas that of the permeate water is lower than the detection limit. These results prove that CIP process has an excellent effect on the recovery of the PVDF membrane assembly.

Based on the nature of the feed water (see table 1 2) and the types of the cleaning reagents (see table 4), we selected sodium hypochlorite, sodium hydroxide and hydrochloric acid as chemical cleaning reagents. The specific cleaning procedure is expressed with the following flowsheet.

(1) $\mathrm{NaOH}$ of $1,000 \mathrm{ppm}+\mathrm{NaClO}$ of 2,000 ppm $\rightarrow$ circulate for $20 \mathrm{~min} \rightarrow$ immersing for $3 \mathrm{~h} \rightarrow$ circulate for $20 \mathrm{~min}$;

(2) Discharge of cleaning solution $\rightarrow$ forward flushing $\rightarrow$ discharge, until $\mathrm{pH}$ of discharge liquor is equal to 7 ;

(3) $8,000 \mathrm{ppm} \mathrm{HCl} \rightarrow$ circulate for $20 \mathrm{~min} \rightarrow$ immersing for $1 \mathrm{~h} \rightarrow$ circulate for $20 \mathrm{~min}$.

The TMP was measured to be approximately $35 \mathrm{kPa}$ when step 2 was finished, and still was $35 \mathrm{kPa}$ when step 3 was finished. It indicated that the membrane assembly had been severely fouled by microorganism and organic substances, instead of inorganic substances.

The water output had been set as $3.7 \mathrm{t} / \mathrm{h}$ and CIP process had been applied since $24 \mathrm{July}$. From figure 1 , we can see that the TMP of the membrane assembly had been recovered to $40 \sim 60 \mathrm{kPa}$, and stayed stable. It indicates that the TMP of PVDF membrane can be effectively recovered by CIP process. Exploration of a more scientific and economical CIP process will be critical in the future study.

\section{Conclusion}

Membrane fouling is an inevitable phenomenon during PVDF membrane filtration. It is always necessary to investigate the nature of the feed water, types of the foulants and degree of the fouling, as well as the membrane properties, cleaning solution properties and cleaning process. A scientific membrane cleaning system should be established to recover the membrane flux rapidly. Correct membrane cleaning is not only a perfect end, but also a brand new start of 
the membrane process.

\section{References}

Kobayashi T \& Fujii N. (2000). Effect of ultrasound on enhanced permeability during membrane water treatment. Japanese Journal of Applied Physics, 39(5), 2980-2981.

Lin, Ye, Chen, Jianyong \& Zhu, Lieping. (2009). Membrane Filtration Technology for Water Supply. Beijing: Chemical Industry Press, p. 94-96, 99.

Liu, Enhua, Huan, Guolan, Du, Qiyun \& Men Penghui. (2003). Research on an effective method of washing membrane: the system of washing membrane with sponge balls. Membrane Science and Technology, 23(6), 65-68.

Liu, Moe, Cai, Bangxiao \& Chen, Yitang. (2005). Application of Membrane Technology in Wastewater Process and Reuse. Beijing: Chemical Industry Press, p. 3, 156-208.

Ridgway H F. (1988). Microbial adhesion and biofouling of reverse osmosis membranes. In Parekh, B (Eds), Reverse Osmosis Technology. New York: Marcel Dekker, p. 429-481.

Wang, Zhiqiang, Cai, Zhenyu, Zhang, Zhigang, Du, Shaoguang \& Li, Juan. (2005). Study on the combination backwashing of gas and permeate as membrane fouling prevention techniques. Techniques and Equipment for Environmental Pollution Control, 6(8), 61-63.

Wu, Guangxia, Zhang, Donghua, Liu, Zhongzhou \& Zeng, Jin. (1999). Cleaning membrane by negative pressure. Membrane Science and Technology, 19(4), 52-55.

Yan, Xushi \& Fan, Jinchu. (1999). Water Supply Engineering. Beijing: China Architecture \& Building Press, p. 125, 233-236.

Zhang, Guojun \& Liu, Zhongzhou. (2003). Progress in membrane cleaning techniques. Technology of Water Treatment, 29(4), 187-190.

Zhang, Zijie, Lin Rongshen \& Jin Rulin. (2000). Sewage Engineering. Beijing: China Architecture \& Building Press, p.1.

Table 1. The foulants on PVDF membrane from different water sources

\begin{tabular}{|c|c|}
\hline Water quality & Foulants \\
\hline Groundwater & Colloid (clay, $\left.\mathrm{SiO}_{2}\right)$, scaling ion $\left(\mathrm{Ca}^{2+}, \mathrm{Mg}^{2+}, \mathrm{Fe}^{2+}, \mathrm{Mn}^{2+}\right.$ and etc.) \\
\hline Surface water & $\begin{array}{r}\text { Colloid (humus, protein), suspension (SS), organism (algae, bacteria, virus, } \\
\text { microorganism), organic foulant (humus, protein, organic substance) }\end{array}$ \\
\hline Domestic wastewater & Organism (bacteria, microorganism), organic foulant (hydrocarbon, nitrogen, phosphorous) \\
\hline Industrial wastewater & Suspension (SS), organism (algae, bacteria, microorganism), organic foulant, oil \\
\hline
\end{tabular}


Table 2. The foulants on PVDF membrane from different industrial wastewaters

\begin{tabular}{|c|c|}
\hline Types of wastewaters & Foulants \\
\hline Wastewater from chemical industrial & $\begin{array}{l}\text { Suspension }(\mathrm{SS}), \mathrm{COD}_{\mathrm{Cr}}, \mathrm{NH}_{3}-\mathrm{N} \text {, grease, phenol, salt, catalyst (Fe, } \mathrm{CO} \text {, } \\
\qquad \mathrm{Ni}, \mathrm{Cr}, \mathrm{Mn}) \text {, and etc. }\end{array}$ \\
\hline Wastewater from metallurgical industrial & $\begin{array}{l}\text { Suspension (SS), } \mathrm{COD}_{\mathrm{Cr}} \text {, metallic ions in terms of calcium, magnesium, } \\
\text { zinc, chromium, lead and etc., rare-earth ions, oil, and tar oil }\end{array}$ \\
\hline $\begin{array}{l}\text { Wastewater from petroleum and } \\
\text { petrochemical industrial }\end{array}$ & $\begin{array}{l}\text { Suspension (SS), } \mathrm{COD}_{\mathrm{Cr}} \text {, oil, phenol, acetone, aromatic hydrocarbon, } \\
\text { benzene, sulfide, soluble salt and etc. }\end{array}$ \\
\hline $\begin{array}{l}\text { Wastewater from textile and dyeing } \\
\text { industry }\end{array}$ & Suspension (SS), $\mathrm{COD}_{\mathrm{Cr}}, \mathrm{BOD}_{5}$, detergent, grease, oil, salt and etc. \\
\hline Wastewater from pharmaceutical industry & Suspension $(\mathrm{SS}), \mathrm{COD}_{\mathrm{Cr}}, \mathrm{BOD}_{5}$, bacterial, virus, microorganism and etc. \\
\hline Wastewater from food industry & $\begin{array}{c}\text { Suspension }(\mathrm{SS}), \mathrm{COD}_{\mathrm{Cr}}, \mathrm{BOD}_{5}, \mathrm{NH}_{3}-\mathrm{N} \text {, bacterial, virus, microorganism } \\
\text { and etc. }\end{array}$ \\
\hline Wastewater from mining industry & $\begin{array}{l}\text { Suspension (SS), sulfate, calcium salt, heavy metal ions such as } \mathrm{Fe}^{3+} \text {, } \\
\qquad \mathrm{Cu}^{2+} \text { and } \mathrm{Zn}^{2+} \text {, oil and etc. }\end{array}$ \\
\hline Wastewater from paper-making industry & Suspension $(\mathrm{SS}), \mathrm{COD}_{\mathrm{Cr}}$ and etc. \\
\hline Wastewater from electroplating industry & $\begin{array}{l}\text { Heavy metal ions such as } \mathrm{Cr}, \mathrm{Ni}, \mathrm{Cd}, \mathrm{Cu}, \mathrm{Zn}, \mathrm{Au} \text { and } \mathrm{Ag} \text {, cyanogens, } \\
\text { surfactant, brightener and etc. }\end{array}$ \\
\hline Wastewater from pesticide industry & Suspension (SS), $\mathrm{COD}_{\mathrm{Cr}}$, phenol, benzene, arsenic, mercury, salt and etc. \\
\hline
\end{tabular}

Table 3. The identification methods of various foulants.

\begin{tabular}{|c|c|}
\hline Foulants & Identification methods \\
\hline Microorganism, bacterial, algae & Observe by microscope \\
\hline $\begin{array}{l}\text { Inorganic scaling deposit (oxide, hydroxide, } \\
\text { insoluble salt, complex compound) }\end{array}$ & $\begin{array}{c}\text { Chemical analysis, inductively coupled plasma spectroscopy (ICP), } \\
\text { atomic absorption spectrometry (AAS) }\end{array}$ \\
\hline Acid-insoluble oxide & $\begin{array}{c}\text { Chemical analysis, inductively coupled plasma spectroscopy (ICP), } \\
\text { atomic absorption spectrometry (AAS) }\end{array}$ \\
\hline Hydrophobic substance & Gas chromatograph (GC), Fourier transform infrared spectroscopy (RTIR) \\
\hline Insoluble ion $\left(\mathrm{Fe}^{2+}, \mathrm{Ca}^{2+}, \mathrm{Mg}^{2+}, \mathrm{Ba}^{2+}\right.$ and etc. $)$ & $\begin{array}{l}\text { Chemical analysis, inductively coupled plasma spectroscopy (ICP), } \\
\text { atomic absorption spectrometry (AAS) }\end{array}$ \\
\hline Colloid & $\begin{array}{l}\text { Fourier transform infrared spectroscopy (RTIR), } \\
\text { scanning electron microscope (SEM) }\end{array}$ \\
\hline Protein & $\begin{array}{l}\text { Fourier transform infrared spectroscopy (RTIR), } \\
\text { scanning electron microscope (SEM) }\end{array}$ \\
\hline Organic substance, oxide and etc. & $\begin{array}{c}\text { Chemical analysis, inductively coupled plasma spectroscopy (ICP), } \\
\text { atomic absorption spectrometry (AAS) }\end{array}$ \\
\hline oil & Chemical analysis \\
\hline
\end{tabular}


Table 4 . The types of foulants and corresponding cleaning reagents.

\begin{tabular}{|c|c|c|}
\hline Foulants & Cleaning reagents and their concentrations & Others \\
\hline Microorganism, bacterial, algae & $\begin{array}{c}\mathrm{NaClO} \text { of } 500 \sim 5,000 \mathrm{ppm} \text {, less than } 10,000 \\
\text { ppm for short-term use }\end{array}$ & $1.5 \% \mathrm{H}_{2} \mathrm{O}_{2}$ \\
\hline $\begin{array}{l}\text { Inorganic scaling deposit (oxide, } \\
\text { hydroxide, insoluble salt, complex } \\
\text { compound) }\end{array}$ & $\begin{array}{c}\mathrm{HCl} \text { with concentration less than } 10 \% \\
\mathrm{HNO}_{3} \text { with concentration less than } 10 \% \\
\text { Oxalic acid with concentration less than } 4 \% \\
\text { Citric acid with concentration less than } 10 \%\end{array}$ & $\begin{array}{l}\text { Citric acid with concentration of } 2 \%, \\
\qquad \begin{array}{c}\mathrm{pH}=7\left(\mathrm{NH}_{3}\right), \\
\text { Tartaric acid }\end{array}\end{array}$ \\
\hline Acid-insoluble oxide & Oxalic acid & Reductants \\
\hline Hydrophobic substance & Specific reagent & Functional reagent + additives \\
\hline Colloid & $10 \% \sim 20 \% \mathrm{NaCl}$ & Other denaturant \\
\hline Protein & Enzyme preparation & Denaturant \\
\hline Organic substance, oxide and etc. & $\mathrm{NaOH}$ with concentration less than $4 \%$ & \\
\hline oil & $0.02 \% \sim 1 \%$ sodium dodecylbenzenesulfonate & Other surfactants \\
\hline
\end{tabular}

Table 5. The quality of outlet water from SBR.

\begin{tabular}{|c|c|c|c|c|}
\hline $\mathrm{pH}$ & $\mathrm{COD}(\mathrm{mg} / \mathrm{L})$ & Ammonia-nitrogen $(\mathrm{mg} / \mathrm{L})$ & Turbidity & Conductivity $(\mu \mathrm{S} / \mathrm{cm})$ \\
\hline $6.85 \sim 7.7$ & $20.79 \sim 29.76$ & $9.52 \sim 21.01$ & $1.4 \sim 3.27$ & $4,200 \sim 5,600$ \\
\hline
\end{tabular}

Table 6. The quality of outlet water from regulation pond.

\begin{tabular}{|c|c|c|c|c|}
\hline $\mathrm{pH}$ & COD $(\mathrm{mg} / \mathrm{L})$ & Ammonia-nitrogen $(\mathrm{mg} / \mathrm{L})$ & Turbidity & Conductivity $(\mu \mathrm{S} / \mathrm{cm})$ \\
\hline $6.9 \sim 7.8$ & $22.1 \sim 30.6$ & $10.27 \sim 22.92$ & $1.07 \sim 4.68$ & $3,600 \sim 4,780$ \\
\hline
\end{tabular}

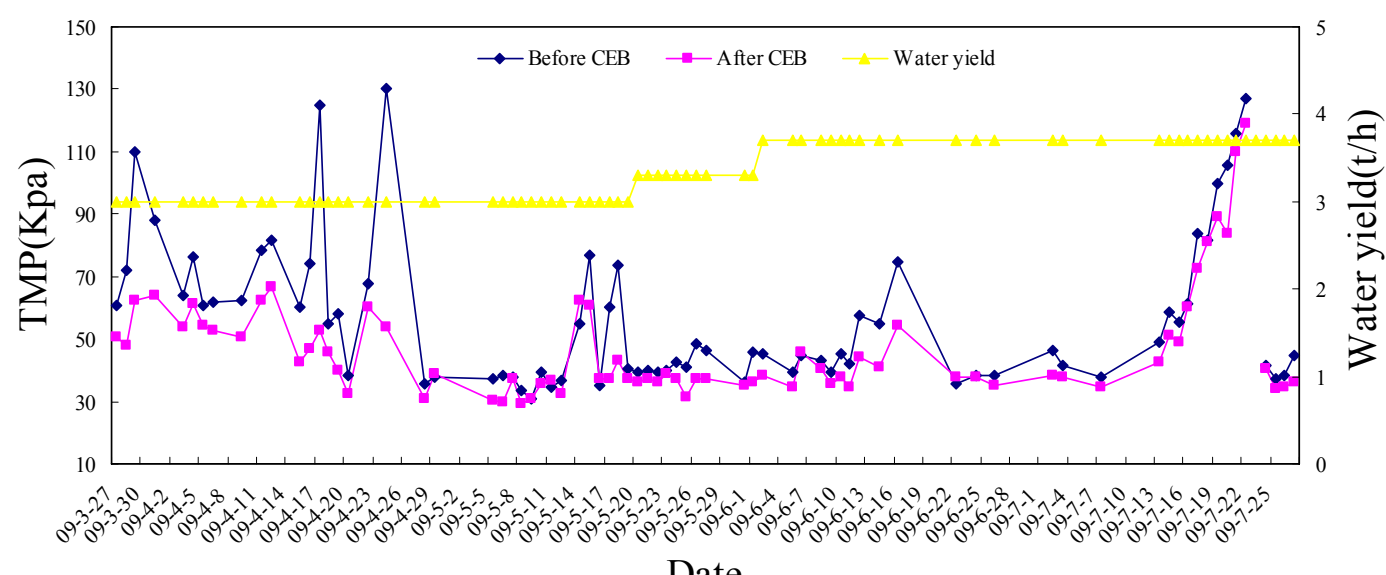

Date

Figure 1. The changes of TMP of the membrane assembly before and after CEB process 


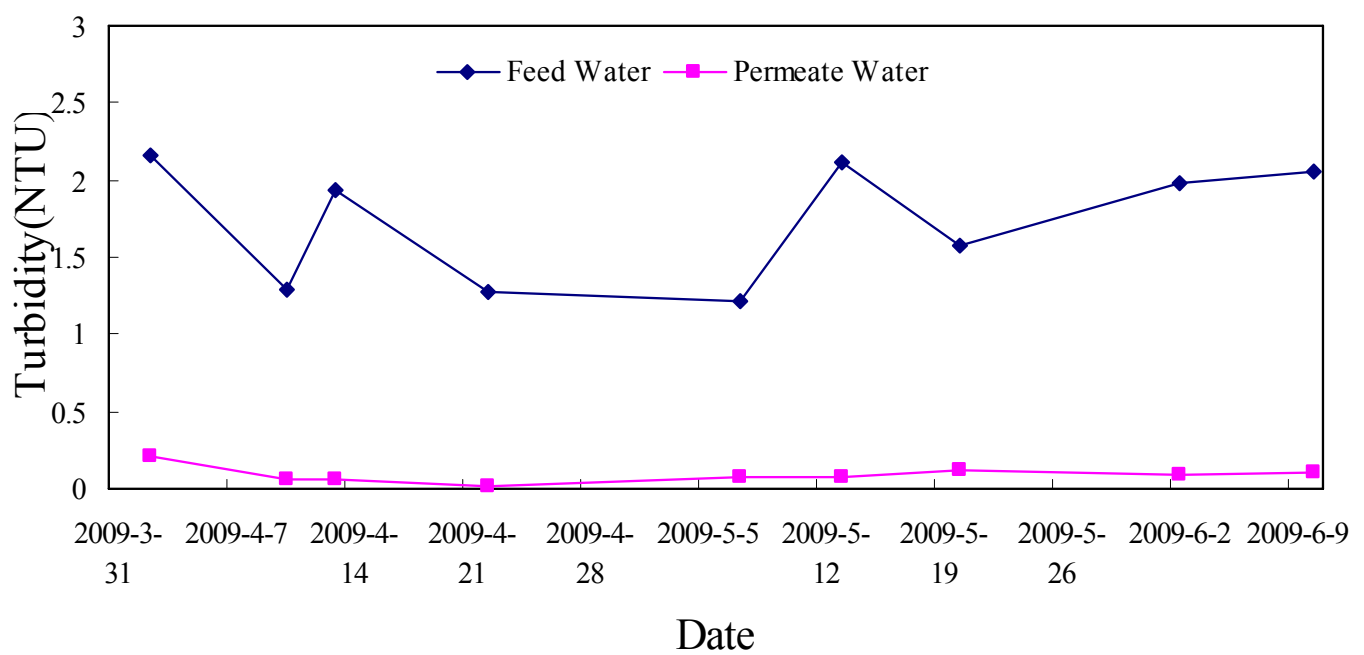

Figure 2 . The turbidity of the feed water and the permeate water

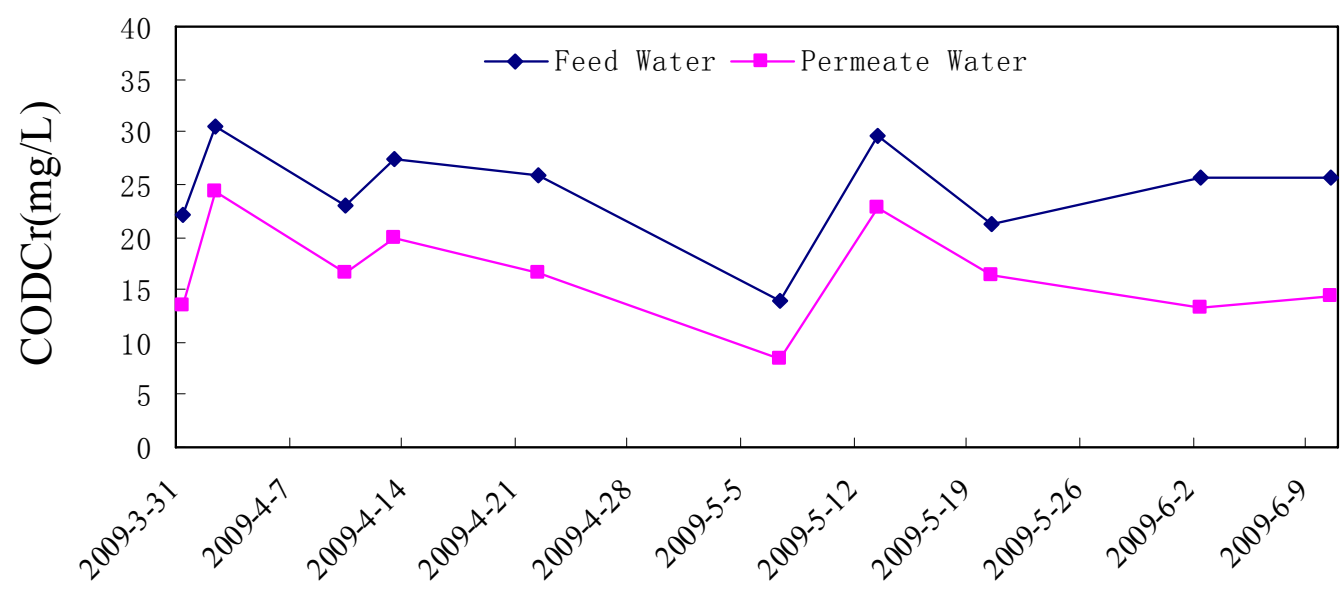

Date

Figure 3. $\mathrm{COD}_{\mathrm{Cr}}$ of the feed water and the permeate water

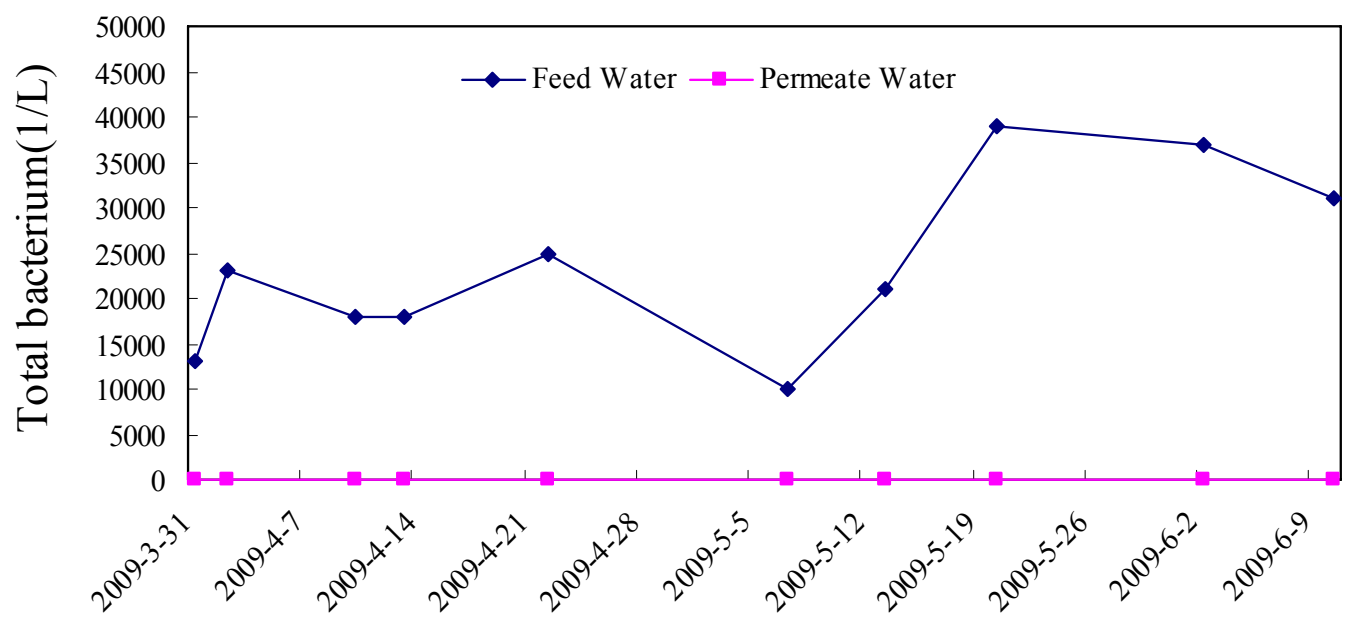

Date

Figure 4. The total bacterial count of the feed water and the permeate water 